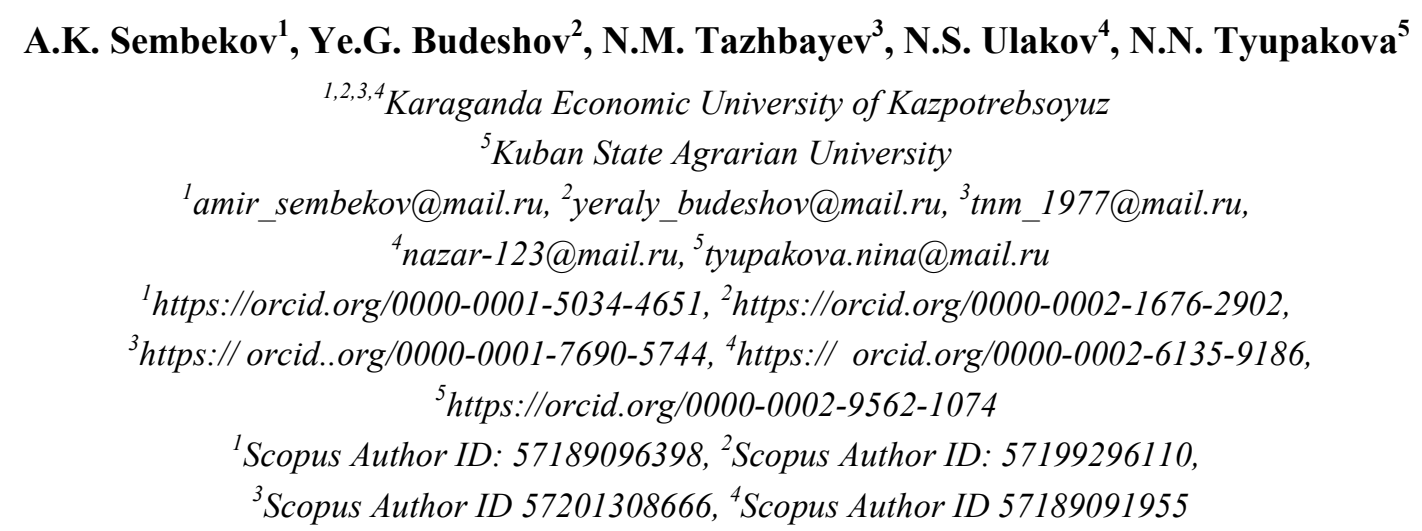

\title{
Digital economy of Kazakhstan: theoretical aspects, development opportunities
}

\section{Abstract}

Object: The aim of the study is to analyze the state of digital transformation of the national economy, identify existing contradictions and risks. Conducting a study of digital economy indices of the Republic of Kazakhstan, building a forecast for the development of digital economy.

Methods: In the course of the study, the following methods were used: observation, generalization, comparison, analysis, systematic approach, systematization of materials, processing.

Results: As a result of the study, a comparative analysis of the theoretical prerequisites for the definition of the term "digital economy" was carried out, differences to the definition based on a study of the opinions, opinions of scientists, experts were generalized, patterns of evolutionary development of the digital economy were revealed. The article substantiates and proposes the author's definition of the concept of "digital economy". The analysis of the state of the digital economy of Kazakhstan is carried out, the main trends, contradictions in the development of the digital economy, other "bottlenecks" that inhibit the development of the digital trend are identified. The forecast assessment of the development of digital literacy of the population for the near future is presented.

Conclusions: Based on the study of digitalization experience of other countries, the main indicators of the development of the country's digital economy are considered, their forecast estimates of development are calculated. On this basis, the author proposed a forecast of the future development of the digital economy. Finally, main conclusions and recommendations for development of the digital economy of Kazakhstan for the medium term are made.

Keywords: digitalization, digital economy, trends, indices, information and communication technologies, digital literacy, forecast.

\section{Introduction}

In the world, the digital economy is being actively introduced into the economic life of many countries, new digital segments of the economy are appearing, elements of digital technologies are being introduced into the production relations of the traditional economy. In digital production, value added is obtained by processing information using digital technology. In the context of digitalization, the final product is the formation of new knowledge based on information processing. The digital economy, as a new way of economic relations, is becoming the basis for development of modern economy as a whole. Digital technologies cause changes in economic relations, increase the level of competitive capabilities of sectors of national economy. Formation of new trends in the transformation of global economy on the way from the economy of goods to the economy of knowledge is taking place (Doucek P. et al., 2017).

For the Kazakhstani economy, digital changes can lead to a real transformation of the national economy on the platform of new digital technological solutions and innovations, raise it to a qualitative level of economic development, which confirms relevance of the study of the problems of the digital economy in the country and the ways of its development.

The aim of the research is to study theoretical aspects of digitalization, analyze the digital transformation of the national economy, identify existing contradictions, development problems, conduct research on the digital economy indices of Kazakhstan, and make a development forecast. 


\section{Literature Review}

The study of digital economy issues is presented in the scientific works of foreign scientists and researchers, such as E. Brynjolfsson, R. Bukht, Zhang L., Chen S., B. Johansson, C. Karlsson, R. Kurzweil, M. Castells, T. Mesenburg, N. Negroponte, M. Skilton, R. Stow, D. Tapscott, R. Hicks, C. Schwab and others. Since the advent of the term "digital economy", a lot of studies, interpretations and forecasts of the development of digital economy have appeared in the scientific community.

The concept of modern digital economy and the study of digital technologies in the world were first set forth in the scientific works of scientists, such as Lancaster F. W., 1996; Crawford W., 1996; Buchanan M., 2008 and others.

Many foreign and Russian scientists, international organizations (Schwab K., 2015; Bukht R., Heeks R., 2019; Bondarenko V.M., 2017; Borisyuk N.K., Smotrina O.S.; Glaz'ev S.Yu.; Golovenchik G.G., 2019; International news agency "Russia Today", 2020) discuss various aspects and features of the concept of "digital economy", but, in general, everyone notes the use of digital technologies as an integral part of the digital economy.

The statement by Schwab K. (WEF, Davos), which considers digital economy through the prism of changing the nature of production or economic relations, changing their subject-object orientation (Schwab K., 2015), is noteworthy.

According to Bukht R. and Heeks R., the definition of digital economy is as follows: "part of the total production volume, which is entirely or mainly produced on the basis of digital technologies by firms whose business model is based on digital products or services" (Bukht R., Heeks R., 2019).

Attention is drawn to digitalization in economic relations in the scientific work of S.Yu. Glazyev, in which it was noted that "Using the capabilities of the information-digital revolution in a changing world economy, the digital revolution complements and significantly expands the possibilities of generating, processing, transmitting, accumulating and assimilating information" (Glaz'ev S.Yu., 2017).

Serious attention in studies of the problems of digital economy has been given in the scientific works of Russian scientists, such as Glazyev S.Yu., Meshcheryakov R., Bondarenko V.M., Borisyuk N.K., Starodubtseva E.B., Markova O.M., Boyko I.P. and a number of others who note that the digital economy is an economic relationship using digital technologies, including the ICT industry, also noting various aspects of the

According to the definition of prof. Bondarenko V.M., "digital economy" is a holistic, systemic, complex problem of finding such model of relations between people that is compatible with the technologies of the 4th industrial revolution, i.e. digital technologies and other high technologies of the 21st century, and in its formation, development and implementation should ensure the achievement of an objectively set goal (Bondarenko V.M., 2017).

Professor Borisyuk N.K. and others (2018), give the following definition of "the digital economy as a system of industrial, economic, social and cultural relations based on the use of digital technologies that shape all processes, turning them into logistic schemes" (Borisyuk N.K., Smotrina O.S.).

Academician of the Russian Academy of Sciences of the Russian Federation, Professor V. Ivanov (2017) gives the broadest definition: "The digital economy is a virtual sphere that complements our reality." At the same time, all mental activity of a person can be attributed to virtual reality, money - the main tool of the economy - is also a product of virtuality (International news agency "Russia Today", 2020).

A serious study was conducted by a Belarusian scientist on the issues of the digital economy (G.G. Golovenchik, 2019), in particular, clarifying the content of the concept of "digital economy", identifying the benefits and assessing the risks of digitalizing the economy. Under the guidance of L.M. Gokhberg, G. Abdrakhmanova et al., the report prepared by the staff of the Institute for Statistical Studies and Economics of Knowledge at the Higher School of Economics has highlighted key aspects of the development of the digital economy, and developed approaches to measuring the digital economy and assessing the impact of the digital economy on economic growth (G. Abdrakhmanova et al., 2019).

According to some scientists (Golovenchik G.G., 2019), Chinese researchers (Zhang L., Chen S., 2019) believe that there are two approaches to the definition of the term "digital economy" - extended and narrow. A narrow definition of the digital economy applies only to ICT-related sectors: telecommunications, the Internet, IT services, the production of components and software, and the field of electronic goods and services. Expanded definition says that "digital economy" is an economic production using digital technologies, including the ICT industry, and part of the industries of the "traditional" economy in which digital technologies are introduced. 
Definitions of the term "digital economy" are well-known by leading international organizations (G.G. Golovenchik, 2019; G.I. Abdrakhmanova et al., 2019; Zhang L., Chen S., 2019), such as the British Computer Community (2014), the Organization for Economic Cooperation and Development (2016), UN Conference on Trade and Development, (2017), World Bank (2016), The Group of Twenty Leading Countries of the World, which note in their definitions that the use of digital technologies and the Internet is a key factor in the digital economy.

Kazakhstani scientists (Karenov R.S., Baimukhamedova G.S., Espolov T., Zhartay Zh.M., Esengeldin B.S., Tull L., Qarmys G.S. and others) in their research also pay attention to the study of various aspects of digital economy. For example, in their research papers they study the methodology issues of digital economy, examine the features of the application of digital technologies in such economic sectors as agribusiness, mining, industry, banking, trade, labor market, etc. (Espolov T., 2018; Karenov R.S., Baymukhamedova G.S., 2019; Qarmys G.S., 2019; Zhartaj Zh.M. et al., 2019).

Definitions of the concepts of "digital economy" evolved along with improvements in technological innovation. In recent decades, the information and communication technology (ICT) sector has developed rapidly and has been marked by the emergence of advanced technological solutions and, accordingly, a new understanding of emerging trends in the digital development of the economy.

As the analysis of the concept of "digital economy" suggested by various scientists or international research centers shows, first of all, the evolutionary characteristic changes of technological development are taken into account, starting from the concept of "information economy", then "Internet economy (Internet communications)", "network economy" (network resources and networks) and at the present stage of economic development - a more expanded concept of "digital economy" (digital technologies, computersoftware tools, information systems, functional mechanisms, the Internet of things, big data analysis, cloud computing). The digital segment, for example, includes companies on digital platforms - the so-called platform companies that sell real goods, for example, Amazon, eBay and Alibaba. Also, similar activities are carried out by companies at the junction of the traditional and digital economies, such as Uber, Airbnb, whose applications are well-known (Huckle S. et. Al., 2016). Branches of the digital economy are emerging that are associated with the digitization of the processes of the traditional economy, part of which is based on the digital format (digitalization economy). The economic dictionary has introduced new terms that characterize the content of the digital economy, such as "digital currency", "digital finance", "digital asset", "digital integration", "digital insurance", "digital bank", "digital financing" and many others, which indicates the expansion of the content of the concept of "digital economy". For example, an article (Ozili P. K., 2018) discusses some issues related to digital finance - an area that has not been critically examined so far in the literature. Digital financing and financial integration have several advantages for users of financial services, providers of digital finance. The digital financing issues discussed in this article (Ozili P. K., 2018; Digital McKinsey, 2017) are relevant for ongoing country-level projects that have greater financial accessibility through digital financing.

We believe that the concept of "digital economy" is broader than the information economy, Internet economy, web economy and other names, as it is broader and integrates them together. As the elements of the digital economy develop, it will be possible to clarify their types and characteristics in the research process.

The digital virtuality of the new economy is that many types of digital economic activity do not create a finished product. Some services of this type may be of an intermediate nature at the "business-to-business" level or at the consumer level; difficulties may arise in calculating value added.

Consequently, digital services are delivered in the virtual space, and it can be difficult to track them. Some scholars claim that measuring a digital economy using traditional economic analysis methods is unrealistic (Golovenchik G.G., 2019; Gohberg L.M., 2019; Zhang L., Chen S., 2019).

All considered definitions of the digital economy in one interpretation or another indicate that digital technologies are the main content of the digital economy. Thus, the digital economy is included in the basis of the new production process (digital technologies, computer-software tools, information systems, functional mechanisms like blockchain, Internet of things, cloud computing and others), forms new economic relations.

Thus, summing up the opinions of many scientists, researchers, we can assume that the most common basis in the definition of the digital economy is that the digital economy is all kinds of economic relations using digital technologies in the network space. 
In our opinion, the digital economy is a system of new economic relations through the use of digital technologies, in which added value is based on the results of processing information in a network format.

Despite the absence of generally accepted criteria for evaluating the digital economy, an analysis of the available data allows us to determine the characteristic features of the digital economy, such as the uneven development of the digital economy; the fast pace of the digital economy in developing countries; the emergence of new specialties and the withering away of many specialties of the traditional economy and higher projected labor productivity.

\section{Methods}

To study the problems of the digital economy and assess the impact on economic growth, the following forms of scientific knowledge are used in the article:

1) review, observation, generalization, comparison and systematization of the materials obtained, their processing through methods of economic analysis

2) through a systematic approach, the functional relationships between variable factors were investigated

3) forecasting of multifactor indices of the digital economy was carried out using economic and mathematical methods of analysis

4) based on systematization of the results of the forecast assessment of digital development of national economy, the conclusions and recommendations of development paths in the medium term are presented.

\section{Results}

Nowadays, the digitalization of the economy is a strategic development priority in many countries. According to forecasts of leading world experts, by 2020 a quarter of the global economy will be digital. The introduction of digital communication technologies in economic and social relations will allow the state and society to rise to a higher level of national development, the effectiveness of their interaction is becoming an increasingly dynamic process. The leading countries of the world have the necessary scientific, technical and technological potentials for the development of digital economy, conducting research in creating new technological solutions, unlike Kazakhstan, as a developing economy with limited financial and scientific and technical capabilities. Leading countries in the field of high technologies, such as Great Britain, the USA, Singapore, the Republic of Korea, Denmark and others note that the qualitative development of the digital sector was preceded by the presence of a fundamental basis of technological progress.

According to the World Bank, the share of the digital economy in the world's total GDP is 5.5\%, analysts predict a significant increase: by 2035, its volume will exceed \$16 trillion (Digital McKinsey, 2017).

At the same time, the analysis of national programs of various countries in the field of digitalization shows a number of serious contradictions of the digital economy:

1) the need to optimize government regulation and the market mechanism of private business, finding the optimal balance for economic growth.

2) digitalization contributes to the formation of social contradictions, the opposition of manpower to digital technology, as a potential increase in unemployment, violation of privacy.

3 ) the problems of introducing a digital economy for a developing country due to the need to ensure digital security on cybersecurity issues and maintaining the confidentiality of personal data.

4) the raw material orientation of the national economy can distract from the laborious work of attracting digital projects and the need for flexible transformations in the business management system.According to the results of a study by Boston Consulting Group (BCG), reflected in the article "Kazakhstan on the path to the digital economy," Kazakhstan ranked 50th in the ranking of 85 states in 2016 in terms of digitalization of the economy and is in the group with an emerging digital economy (Kemp, S., 2017; On the approval of the State Digital Kazakhstan Program). As noted in the e-intensity rating of the international consulting company The Boston Consulting Group, in terms of the current level of digitalization, Kazakhstan is a catchup country. In world practice, the assessment of digitalization is calculated on the basis of 4 indices, which make it possible to assess the level of use of digital technologies in the activities of consumers, companies and government agencies, the availability of ICT infrastructure and the development of digital innovations.

Kazakhstan has adopted the state program Digital Kazakhstan, aimed at creating the digital economy of the future in the long term. As noted in the document, the program is aimed at the digital transformation of traditional sectors of the economy, the development of human capital, the digitalization of government agencies, the development of digital infrastructure. 
For analysis from the World Economic Forum Global Competitiveness Index report for 2019, of the total number of 12 factors and (103) indicators, we selected those that characterize the level of the digital component of the economy of Kazakhstan (table 1).

Table 1. Global competitiveness index indicators of Kazakhstan

\begin{tabular}{|c|l|c|}
\hline № & \multicolumn{1}{|c|}{ Indicators/parameters } & Year 2019 \\
\hline 1. & E-participation & 41 \\
\hline 2. & Adaptability of the legal framework to digital business models & 43 \\
\hline 4. & Internet users & 47 \\
\hline 5. & Digital skills among active population & 43 \\
\hline 6. & Education and skills & 57 \\
\hline 6. & ICT implementation & 44 \\
\hline 7. & Innovative capacity & 95 \\
\hline 8. & R\&D expenses & 101 \\
\hline 9. & Research and development & 115 \\
\hline 10. & Growth of innovative companies & 107 \\
\hline 11. & Venture Capital availability & 89 \\
\hline Note - compiled by the authors based on the WEF GCI report for year 2019 (Center for strategic initiatives, 2019). \\
\hline
\end{tabular}

The main conclusion is that Kazakhstan, in general, according to the many digital economy indicators, has ratings in the report of the Global Competitiveness Index according to the WEF report (41-47) out of 141 evaluated countries, but the positions in the "Innovative Capacity" factor are the weakest - 95th place, low indices, such as R\&D expenses - 101st place, Research and Development - 115th place, availability of Venture Capital - 89th place, Education and Skills - 57th place, Growth of innovative companies - 107th place. Such an assessment, calculated by the authors on the basis of GCI indicators analysis, in general, coincides with the e-intensity rating of the international consulting company The Boston Consulting Group.

It is generally accepted in world practice that in order to assess the country's digital competitiveness, three main factors must be taken into account:

1) knowledge (the country's ability to learn new technologies);

2) technology (the ability to develop digital technology);

3) readiness for the future (ability to technologicalize the economy and society), (IMD World Competitiveness Center, 2019).

Accordingly, despite the good position of Kazakhstan in some indices, there are serious problems in the field of ICT security, the growth of digital companies, their innovative capabilities (research funding, $\mathrm{R} \& \mathrm{D}$, venture capital).

\section{Discussion}

Data should be analyzed based on 4 indices of the digital economy in order to assess the level of digital potential of Kazakhstan:

1) the level of digital development of the public sector.

2) digital literacy of the population;

3) digital business, digital companies, their services;

4) availability of ICT infrastructure and the development of digital innovation.

1. The level of digital development of the public sector. Kazakhstan ranked 28th in the UN ranking of e-government development for 2019 (39 last year, 2018). At the same time, Kazakhstan entered the top ten countries in Asia, taking 5th place, and the leaders are South Korea, Singapore and Japan. The e-government development index includes access characteristics such as infrastructure level and education level to reflect how a country uses information technology. The relationship between e-government development and the digital economy is confirmed empirically in an international study of 67 countries using authoritative archival data, primarily in the UN e-government survey and the Economic Intelligence rating for the digital economy (Zhao F. et al., 2015).

2. Digital literacy of the population. Based on the data of the UNESCO Adult Literacy Report, which are compiled from national estimates and estimates based on the Global Literacy Prediction Model, we have compiled a user chart on the Kazakhstan age scale (Figure 1).

Of the majority of users in Kazakhstan visiting the e-government website, the most active ICT users were citizens from 24 to 34 years old $(56.6 \%), 14.6 \%$ of the site users are representatives of the age group from 18 to 24 years old, $11 \%$ - from 35 up to 44 years old. Less than all users over 55 turned out to be only 
$3.82 \%$ of the total number of ICT users. For 2018, the proportion of the population aged 6 to 74 years with the skills to use a personal computer, smartphone, tablet, laptop; standard programs; receiving services and services via the Internet, amounted to $79.6 \%$ than a year earlier $(77.1 \%)$.

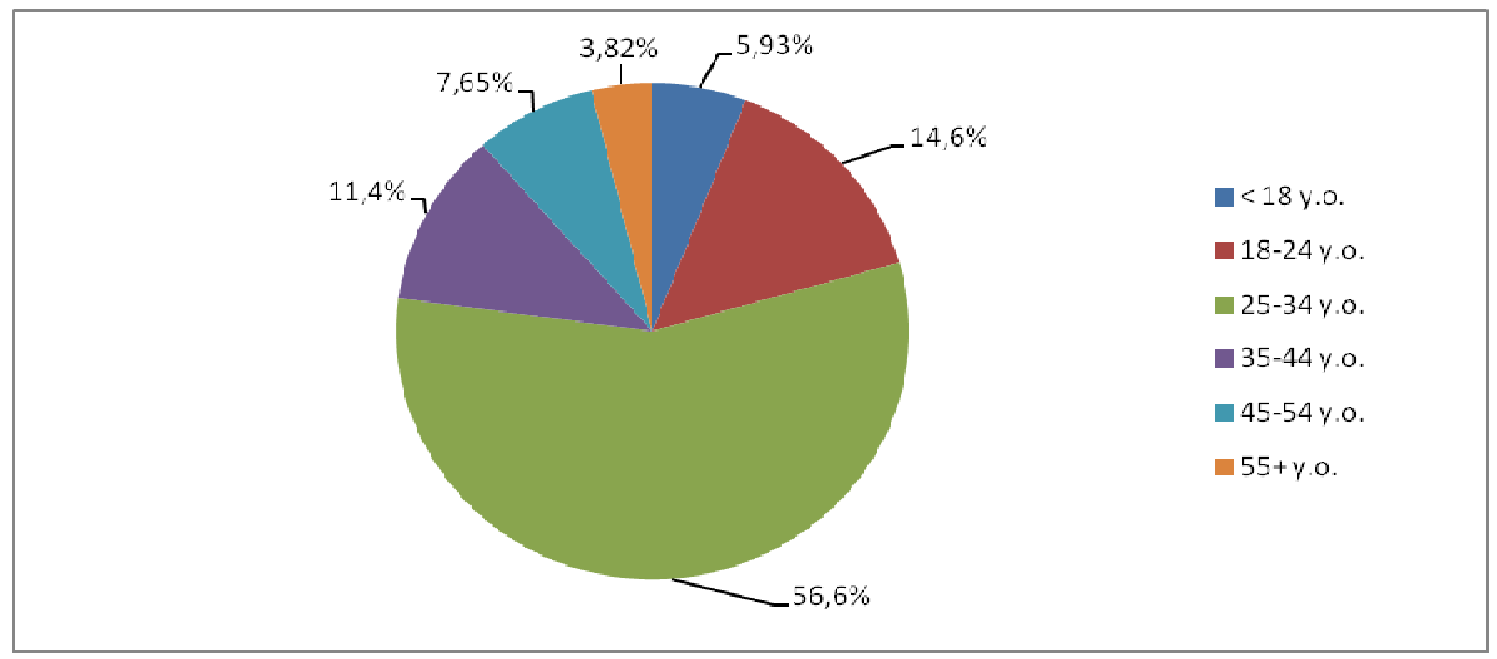

Figure 1. Age category of active users of digital technologies of the Republic of Kazakhstan

Note - based on the UNESCO Adult Literacy Report (UNESCO, 2019)

Let's calculate the forecast for the development of digital literacy in the near future according to the Student's method. Forecast indicators are compiled for 2020, 2021 and 2022 (Figure 2). As the forecast model showed, in order to achieve the $80 \%$ level of digital literacy in the country, it is necessary to train about 468 thousand people in digital competencies, which include basic digital skills, information security, electronic commerce, and the use of electronic and open government. The existing dependence of the indicators revealed the need to improve skills: 1. Basic digital skills; 2. Skills of using "electronic government"; 3. Skills of "electronic commerce"; 4. Information security skills.

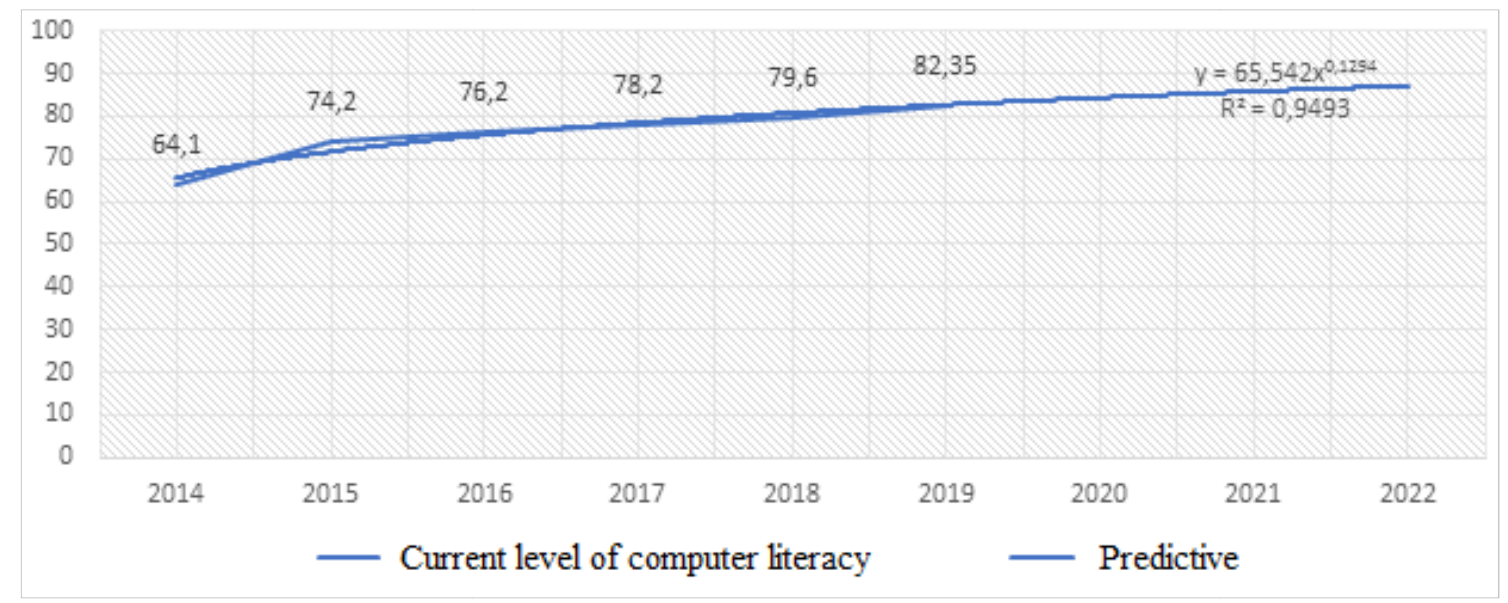

Figure 2. Predictive estimation of digital literacy of the population until 2022, in \%.

The results of the study show that at present, digital knowledge and skills are becoming an urgent need and a prerequisite for success for most citizens of the country, they are needed to increase the effectiveness of employee qualifications. During the study, the results of the relationship of these indicators were obtained.

3. Development and availability of ICT, digital business. The ICT market is a key factor in the successful development of the digital economy in the country. Discussions at the 2017 World Telecommunication Development Conference in Buenos Aires, Argentina, October 9-20, 2017, on "ICTs for sustainable development," contributed to the formulation of strategic goals aimed at accelerating the pace of achievement of countriesb (International Telecommunications Union, 2017). According to the current state of the ICT sector in the country, the ICT market in Kazakhstan is developing one-sidedly and weakly. Hardware prevails in the ICT market, it accounts for the majority of the market - almost $78.7 \%$. Digital services, production of 
digital products, software are poorly developed. According to the American company, in the global IT market, consulting and a variety of services account for $19 \%$, equipment $-23.3 \%$, software $-21 \%$ (the rest is telecommunications services and equipment, etc.) (International Data Corporation, 2019; JSC "National Infocommunication Holding "Zerde", 2019; Carrie Johnson, 2018).

The main factors, according to many scientists, in ensuring high rates of economic growth is the level of human capital (in fact, the level of education and skills of the workforce), the level of application of technological solutions, including digital technology.

Identified existing ICT problems require the search for possible solutions to the development of the ICT industry and, in general, the digital industry in the Republic of Kazakhstan. Based on the analysis of 4 subindices of the digital sector, a summary table 2 is compiled based on data from the digital industry of Kazakhstan.

Table 2. Indicators of the development of the digital industry in the Republic of Kazakhstan

\begin{tabular}{|c|c|c|c|c|c|c|}
\hline Year & $\begin{array}{c}\text { ICT industry } \\
\text { production volume, } \\
\text { mln KZT }\end{array}$ & $\begin{array}{c}\text { Number of IT } \\
\text { companies }\end{array}$ & $\begin{array}{l}\text { The volume of } \\
\text { ICT services, } \\
\text { mln KZT }\end{array}$ & $\begin{array}{l}\text { E-Gov } \\
\text { (services } \\
\text { provided) }\end{array}$ & $\begin{array}{l}\text { E-Government } \\
\text { Development } \\
\text { Index }\end{array}$ & $\begin{array}{c}\text { The level of computer } \\
\text { literacy of the } \\
\text { population, } \%\end{array}$ \\
\hline 2019 & 2400000 & 16863 & 1345246 & 23500000 & 28 & 82,35 \\
\hline 2018 & 2125624 & 13295 & 1118823 & 27500000 & 39 & 79,6 \\
\hline 2017 & 1866000 & 15288 & 1034849 & 34000000 & 32 & 78,2 \\
\hline 2016 & 1652000 & 15720 & 944398 & 26000000 & 33 & 76,2 \\
\hline 2015 & 1606000 & 14849 & 882915 & 24500000 & 31 & 74,2 \\
\hline 2014 & 1557000 & 11668 & 830486 & 34500000 & 28 & 64,1 \\
\hline
\end{tabular}

Based on the analysis of the digital economy indices of Kazakhstan (Figures 1,2) and the data in Tables 1,2 , it became possible to assess the level of development of the digital economy in Kazakhstan and the prospects for its development in the coming period.

\section{Conclusions}

As a result of the study, the following trends were identified and conclusions were drawn on the development of the digital economy of Kazakhstan:

1. According to the assessment of the current state of the ICT sector in Kazakhstan, it has been established that the ICT market is developing one-sidedly and weakly, sector development is dominant - the acquisition of hardware $(78.7 \%)$.

2. They have not received proper development in the ICT industry: e-commerce, software development, digital services, and the digital economy indices such as government services and digital literacy of the population have a good pace of development, but, nevertheless, these positions lag behind the level of developed countries;

3. The level of the "innovative opportunities" indicator remains low compared to many countries; accordingly, such indices as R\&D expenses, research, and the growth of domestic innovative companies are weak.

4. It is necessary to adopt a set of digital legislation in order to remove the stiff administrative, organizational, legal and other obstacles that impede, first of all, the development of ICT technology sectors.

5. It is necessary to step up the creation of a full-fledged digital infrastructure for the effective development, in general, of digitalization in the country. It is necessary to actualize the solution of issues of financial support for high-tech digital projects, $R \& D$, the introduction of innovative digital business models and ICT.

6. The effectiveness of interaction is becoming relevant: 1) the state, 2) enterprises and 3) universities. Based on the study, the education system in Kazakhstan should take into account modern changes in the economic trend of national development in order to meet the requirements of digital transformation:

1) to give priority attention to the problems of the development of human capital on a systematic basis. To take into account the mistakes of state policy in the training of specialists in higher education, to eliminate business approaches in the educational process. 
2) a financial support model for venture technology solutions should be created, support for start-up projects of young scientists, investments in educational programs of the digital economy.

3) special attention should be paid to the problems of training and professional development of working specialists in economic sectors. Particular measures should be taken to prevent "brain drain", attract and retain talented specialists, as well as return them to the country.

\section{References}

Abdrahmanova G.I., Vishnevskij K.O., Gohberg L.M. (2019). Chto takoe cifrovaja jekonomika? Trendy, kompetencii, izmerenie [What is a digital economy? Trends, competencies, measurement]. Nac. issled. un-t "Vysshaja shkola jekonomiki". - M.: Izd. dom Vysshej shkoly jekonomiki [National Research University Higher School of Economics. - Moscow: HSE Publishing House], 82

AO "Nacional'nyj infokommunikacionnyj holding "Zerde" [Zerde National Infocommunication Holding]. (2019). Otchet "Razvitie otrasli IKT v Respublike Kazahstan po itogam 2019 goda" [Report "Development of the ICT industry in the Republic of Kazakhstan in 2019"']. Retrieved from https://zerde.gov.kz/activity/analysis-anddevelopment-of-ict/the-development-of-the-ict-sector-in-the-republic-of-kazakhstan/

Bondarenko V.M. (2017). Mirovozzrencheskij podhod k formirovaniju, razvitiju i realizacii "cifrovoj jekonomiki" [Worldview approach to the formation, development and implementation of the digital economy]. Sovremennye informacionnye tehnologii i IT-obrazovanie [Modern information technology and IT education], 13, 1, 237-251.

Borisjuk N.K., Smotrina O.S. (2018). Cifrovaja jekonomika: opredelenie i soderzhanie [Digital economy: definition and content]. FGBOU VO "Orenburgskij gosudarstvennyj universitet". - Izdatel'stvo: Orenburgskij gosudarstvennyj universitet [FSBEI HE "Orenburg State University". - Orenburg State University Publishing House], 1378-1383

BUCHANAN M. (2008). THE LAW OF ACCELERATING RETURNS. NATURE PHYSICS. NATURE PUBLISHING GROUP.

HTTPS://DOI.ORG/10.1038/NPHYS1010

Bukht R., Heeks R. (2019). Defining, Conceptualising and Measuring the Digital Economy. SSRN Electronic Journal. https://doi.org/10.2139/ssrn.3431732

Carrie Johnson. (2018). Predictions 2019: Transformation Goes Pragmatic. - (https://go.forrester.com/blogs/predictions2019-transformation-goes-pragmatic/)

Centr strategicheskih iniciativ [Center for Strategic Initiatives]. (2019). Podrobnyj otchet o rejtinge konkurentosposobnosti (GIK VJeF) [Detailed Competitiveness Rating Report (GIC WEF)]. Retrieved from https://csi.kz/news/09102019

CRAWFORD W. (1996). THE DIGITAL ECONOMY: PROMISE AND PERIL IN THE AGE OF NETWORKED INTELLIGENCE. THE JOURNAL OF ACADEMIC LIBRARIANSHIP, 22(5), 397. HTTPS://DOI.ORG/10.1016/S0099-1333(96)90098-1

Digital McKinsey. (2017). Cifrovaja Rossija: novaja real'nost' [Digital Russia: a new reality]. Retrieved from http://www.tadviser.ru/images/c/c2/Digital-Russia-report.pdf

Doucek P., Fischer J., Novotny O. (2017). Digital economy. In IDIMT 2017: Digitalization in Management, Society and Economy - 25th Interdisciplinary Information Management Talks. Trauner Verlag Universitat, 33-40. https://doi.org/10.29322/ijsrp.9.12.2019.p9650

Espolov T. (2018). Cifrovizacija APK - trebovanie novogo vremeni [Digitalization of the agro-industrial complex the requirement of a new time]. Sovremennoe obrazovanie [Modern education], 1(109), $26-29$

Glaz'ev S.Ju. (2017). Velikaja cifrovaja revoljucija: vyzovy i perspektivy dlja jekonomiki XXI veka [The Great Digital Revolution: Challenges and Prospects for the 21st Century Economy]. Informacionnoe agentstvo "Avrora" [News agency "Aurora"]. Retrieved from https://www.glazev.ru/artides/6-jekonomika

“Global Education Monitoring Report 2019". (2019). - UNESCO. Retrieved from https://www.sdg4education2030.org/global-education-monitoring-report-2019-unesco-november-2020

Golovenchik G.G. (2019). Cifrovizacija belorusskoj jekonomiki v sovremennyh uslovijah globalizacii [Digitalization of the Belarusian economy in modern conditions of globalization]. Minsk: Izd. centr BGU [Minsk: Publishing center $B S U], 257$

Huckle S., Bhattacharya R., White M., Beloff N. (2016). Internet of Things, Blockchain and Shared Economy Applications. In Procedia Computer Science, 58, 461-466. https://doi.org/10.1016/j.procs.2016.09.074

IMD World Competitiveness Center (WCC). (2019). Kazahstan podnjalsja na 3 stupeni v rejtinge cifrovoj konkurentosposobnosti [Kazakhstan climbed 3 steps in the ranking of digital competitiveness]. Retrieved from https://inbusiness.kz/ru/last/kazahstan-podnyalsya-na-tri-stupeni-v-rejtinge-cifrovoj-konkurentosposobnosti

International Telecommunications Union. (2017). ICT facts and figures 2017.ITU, 1-8. https://doi.org/10.1787/9789264202085-5-en

Karenov R.S., Bajmuhamedova G.S. (2019). Innovacionnye reshenija na osnove sozdanija, vnedrenija i kommercializacii cifrovyh tehnologij (Innovation solutions based on creation, implementation and commercializa- 
tion of digital technologies). Vestnik Karagandinskogo universiteta. Serija “Jekonomika” (Bulletin of the Karaganda university. "Economy series"), 1(93), 84-97

Karmys F.S. (2019). Vlijanie cifrovizacii na rynok truda (Impact of digitalization on the labor market). Vestnik Karagandinskogo universiteta. Serija "Jekonomika" (Bulletin of the Karaganda university. "Economy series"), 1(93), 256-261

“Kazakhstan Market 2019 Analysis". (2019). International Data Corporation. Retrieved from https://www.idc.com/cis/research/published_reports

Kemp S. (2017). Digital in 2017: Global Overview. We Are Social and Hootsuite, 107. https://doi.org/https://wearesocial.com/blog/2017/01/digital-in-2017-global-overview

Lancaster F. W. (1996). Being digital. Nicholas negroponte. The Library Quarterly, 66(2), 208-210. https://doi.org/10.1086/602868

Mezhdunarodnoe informacionnoe agentstvo "Rossija segodnja" [International news agency "Russia Today"]. (2020). Cifrovaja jekonomika: kak specialisty segodnja ponimajut jetot termin [Digital economy: how specialists today understand this term]. Retrieved from https://ria.ru/20200315/1568635967.html

Ob utverzhdenii Gosudarstvennoj programmy "Cifrovoj Kazahstan" [About the approval of the State program "Digital Kazakhstan"]. Postanovlenie Pravitel'stva Respubliki Kazahstan ot 12 dekabrja 2017 goda № 827 [Decree of the Government of the Republic of Kazakhstan dated December 12, 2017 No. 827]. Retrieved from http://adilet.zan.kz/rus/docs/P1700000827

Ozili P. K. (2018). Impact of digital finance on financial inclusion and stability. Borsa Istanbul Review, 18(4), 329-340. https://doi.org/10.1016/j.bir.2017.12.003

Shvab K. (2016). Chetvertaja promyshlennaja revoljucija [The Fourth Industrial Revolution]. Izdatel'stvo "JeKSMO” ["EXMO” Publishing house], 208

Zhao F., Wallis J., Singh M. (2015). E-government development and the digital economy: a reciprocal relationship. Internet Research, 25(5), 734-766. https://doi.org/10.1108/IntR-02-2014-0055).

Zhang L., Chen S. (2019). China's digital economy: Opportunities and risks. International Organisations Research Journal, 14(2), 275-303. https://doi.org/10.17323/1996-7845-2019-02-11

Zhartaj Zh.M., Esengel'din B.S., Tyll L. (2019). Eurazijalyk jekonomikalyk odak mushememleketterdin onerkasip salalaryn cifrlyk transformacijalau zhane olardyn basekege kabilettiligin zhogarylatu (Digital transformation of industries of the member states of the Eurasian economic Union and increase of their competitiveness). Vestnik Karagandinskogo universiteta. Serija “Jekonomika” (Bulletin of the Karaganda university. "Economy series"), $1(93), 22-30$

\section{А.К. Сембеков, Е.Г. Будешов, Н.М. Тажбаев, Н.С. Улаков, Н.Н. Тюпакова}

\section{Қазақстанның цифрлық экономикасы: теориялық аспектілері, даму мүмкіндіктері}

\section{Аңдатпа}

Maқ̧cambl: Зерттеудің мақсаты ұлттық экономиканың цифрлық түрлену жағдайын талдау, бар қайшылықтар мен қауіптерді анықтау болып табылады. Цифрлық экономиканың даму болжамын құра отырып, Қазақстан Республикасының цифрлық экономикасының индекстерін зерттеу.

Әдісі: Зерттеу барысында келесідей әдістер қолданылған: бақылау, жалпылау, салыстыру, талдау, жүйелік тәсілдеме, ақпараттарды жүйелеу, өңдеу.

Kорытынды: Зерттеу нәтижесінде «цифрлық экономика» терминін анықтаудағы теориялық алғышарттарға салыстырмалы талдау жүргізіліп, анықтамаға қатысты ғалымдар мен сарапшылардың көзқарастары мен пікірлерін зерттеу негізінде айырмашылықтар жалпыланып, цифрлық экономиканың эволюциялық даму заңдылықтары анықталған. Мақалада «цифрлық экономика» түсінігіне авторлық анықтама негізделіп ұсынылған. «Цифрлық Қазақстан» мемлекеттік бағдарламасының жүзеге асырылу жағдайына талдау жүргізіліп, цифрлық экономиканың негізгі үрдістері, даму қайшылықтары мен Қазақстанның цифрлық даму үрдістерінің өрлеуін тежеуші басқа да мәселелер айқындалған.

Тұжырымдама: Басқа елдердің цифрландыру тәжірибелерін зерттеу негізінде елдегі цифрлық экономиканың негізгі даму көрсеткіштері қарастырылып, олардың дамуындағы болжамды бағалар есептелінді. Соның негізінде цифрлық экономиканың келешектегі даму болжамы ұсынылған. Қорытындылай келе, орта мерзімді болашаққа Қазақстан цифрлық экономикасының дамуына қатысты негізгі тұжырымдар жасалып, ұсыныстар келтірілген.

Кілm сөздер: цифрландыру, цифрлық экономика, үрдістер, ұлттық бағдарламалар, индекстер, цифрлық бәсекеге қабілеттілік, ақпараттық-коммуникациялық технологиялар, болжау. 


\section{А.К. Сембеков, Е.Г. Будешов, Н.М. Тажбаев, Н.С. Улаков, Н.Н. Тюпакова}

\section{Цифровая экономика Казахстана: теоретические аспекты, возможности развития}

\section{Аннотация}

Цель: Целью исследования является анализ состояния цифровой трансформации национальной экономики, выявление существующих противоречий и рисков. Проведение исследования индексов цифровой экономики Республики Казахстан, построение прогноза развития цифровой экономики.

Meтоды: В ходе исследования были использованы методы: наблюдение, обобщение, сравнение, анализ, системный подход, систематизация материалов, обработка.

Pезультаты: В результате исследования проведен сравнительный анализ теоретических предпосылок к определению термина «цифровая экономика», обобщены различия к определению на основе изучения мнений, взглядов ученых, экспертов, выявлены закономерности эволюционного развития цифровой экономики. В статье обосновано и предложено авторское определение понятия «цифровая экономика». Проведен анализ состояния цифровой экономики Казахстана, выявлены основные тенденции противоречий развития цифровой экономики, другие «узкие» места, тормозящие прогресс развития цифровой тенденции. Представлена прогнозная оценка развития цифровой грамотности населения на ближайшую перспективу.

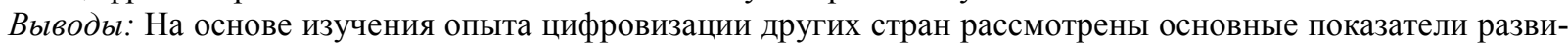
тия цифровой экономики страны, рассчитаны их прогнозные оценки развития. На этой основе предложен прогноз развития цифровой экономики на будущее. В заключении сделаны основные выводы и рекомендации развития цифровой экономики Казахстана в среднесрочной перспективе.

Ключевые слова: цифровизация, цифровая экономика, тенденции, индексы, информационнокоммуникационные технологии, цифровая грамотность, прогноз.

\section{References}

Buchanan M. the law of accelerating returns [текст] / M. Buchanan // Nature Physics. Nature Publishing Group. 2008. - (https://doi.org/10.1038/nphys1010)

Bukht R. Defining, Conceptualising and Measuring the Digital Economy [Текст] / R. Bukht, R. Heeks // SSRN Electronic Journal. — 2019. — (https://doi.org/10.2139/ssrn.3431732)

Carrie Johnson. Predictions 2019: Transformation Goes Pragmatic [Текст] /Johnson Carrie. - 2018. (https://go.forrester.com/blogs/predictions-2019-transformation-goes-pragmatic/)

Crawford W. The digital economy: Promise and peril in the age of networked intelligence [Текст] / w. Crawford // The Journal of Academic Librarianship. — 1996. — № 22(5). — C. 397.

Doucek P. Digital economy [Текст] / P. Doucek, J. Fischer, O. Novotny // In IDIMT 2017: Digitalization in Management, Society and Economy - 25th Interdisciplinary Information Management Talks. Trauner Verlag Universitat. - 2017. - C. 33-40.

«Global Education Monitoring Report 2019». UNESCO. — (https:/www.sdg4education2030.org/global-educationmonitoring-report-2019-unesco-november-2020)

Huckle S., Bhattacharya R., White M., Beloff N. Internet of Things, Blockchain and Shared Economy Applications [Текст] / S. Huckle, R. Bhattacharya, M. White, N. Beloff // In Procedia Computer Science. — 2016. — Vol. 58. — C. 461-466.

ICT facts and figures 2017. International Telecommunications Union. — (https://doi.org/10.1787/9789264202085-5-en)

$$
\text { «Kazakhstan Market } 2019 \text { Analysis». International Data Corporation. }
$$
(https://www.idc.com/cis/research/published_reports)

Kemp S. Digital in 2017: Global Overview [Текст] / S. Kemp // We Are Social and Hootsuite. — 2017. — C. 107. — (https://doi.org/https://wearesocial.com/blog/2017/01/digital-in-2017-global-overview)

Lancaster F.W. Being digital. Nicholas Negroponte [Текст] / F.W. Lancaster // The library quarterly. — 1996. № 66(2). - C. 208-210.

Ozili P.K. Impact of digital finance on financial inclusion and stability [Текст] / P.K. Ozili // Borsa Istanbul Review. 2018. 一 № 18(4). — C. 329-340.

Zhao F. E-government development and the digital economy: a reciprocal relationship [Tекст] / F. Zhao, J. Wallis, M. Singh // Internet Research. — 2015. — № 25(5). — C. 734-766.

Zhang L. China's digital economy: Opportunities and risks [Текст] / L. Zhang, S. Chen // International Organisations Research Journal. - 2019. — № 14(2). - C. 275-303.

Абдрахманова Г.И. Что такое цифровая экономика? Тренды, компетенции, измерение [Текст] / Г.И. Абдрахманова, К.О. Вишневский, Л.М. Гохберг // Нац. исслед. ун-т «Высшая школа экономики». М.: Изд. дом «Высш. шк. экономики», 2019. - С. 82.

Бондаренко В.М. Мировоззренческий подход к формированию, развитию и реализации «цифровой экономики» [Текст] / В.М. Бондаренко // Современные информационные технологии и ИТ-образование. — 2017. — T. 13. - № 1. - C. 237-251. 
Борисюк Н.К. Цифровая экономика: определение и содержание [Текст] / Н.К. Борисюк, О.С. Смотрина // ФГБОУ ВО «Оренбургский государственный университет». — Оренбург: Изд-во Оренбург. гос. ун-та, 2018. - С. $1378-1383$.

Глазьев С.Ю. Великая цифровая революция: вызовы и перспективы для экономики XXI века [Текст] / С.Ю. Глазьев // Информационное агентство «Аврора». — 2017. — (https://www.glazev.ru/artides/6-jekonomika)

Головенчик Г.Г. Цифровизация белорусской экономики в современных условиях глобализации [Текст] / Г.Г. Головенчик. - Минск: Изд. центр БГУ, 2019. - С. 257.

Есполов Т. Цифровизация АПК - требование нового времени [Текст] / Т. Есполов // Современное образование. - 2018. — № 1(109). - С. 26-29.

Жартай Ж.М. Еуразиялық экономикалық одақ мүше мемлекеттердің өнеркәсіп салаларын цифрлық трансформациялау және олардың бәсекеге қабілеттілігін [Текст] / Ж.М. Жартай, Б.С. Есенгельдин, Л. Тылл // Вестн. Караганд. ун-та. Сер. Экономика. — 2019. — № 1(93). - С. 22-30.

Казахстан поднялся на 3 ступени в рейтинге цифровой конкурентоспособности. IMD World Competitiveness Center (WCC). — 2019. (https://inbusiness.kz/ru/last/kazahstan-podnyalsya-na-tri-stupeni-v-rejtinge-cifrovojkonkurentosposobnosti)

Каренов Р.С. Инновационные решения на основе создания, внедрения и коммерциализации цифровых технологий [Текст] / Р.С. Каренов, Г.С. Баймухамедова // Вестн. Караганд. ун-та. Сер. Экономика. — 2019. — № 1(93). - С. 84-97.

Қармыс Ғ.С. Влияние цифровизации на рынок труда [Текст] / Ғ.С. Қармыс // Вестн. Караганд. ун-та. Сер. Экономика. - 2019. - № 1(93). - С. 256-261.

Отчет «Развитие отрасли ИКТ в Республике Казахстан по итогам 2019 года». АО «Национальный инфокоммуникационный холдинг «Зерде». - (https://zerde.gov.kz/activity/analysis-and-development-of-ict/thedevelopment-of-the-ict-sector-in-the-republic-of-kazakhstan/)

Подробный отчет о рейтинге конкурентоспособности (ГИК ВЭФ). Центр стратегических инициатив. — 2019. — (https://csi.kz/news/09102019)

Постановление Правительства Республики Казахстан от 12 декабря 2017 года № 827. Об утверждении Государственной программы «Цифровой Казахстан». — (http://adilet.zan.kz/rus/docs/P1700000827)

Цифровая Россия: новая реальность. Digital McKinsey. — 2017. — (http://www.tadviser.ru/images/c/c2/DigitalRussia-report.pdf)

Цифровая экономика: как специалисты сегодня понимают этот термин. Международное информационное агентство «Россия сегодня». — 2020. — (https://ria.ru/20200315/1568635967.html)

Шваб К. Четвертая промышленная революция [Текст] / К. Шваб. — М.: Эксмо, 2016. — С. 208. 